are thus much more expensive now than they were ten years ago, a situation which is often described in terms of a 'sophistication factor'. In the case of imported instruments, which account for a greater proportion of the research type than the routine type in Britain, the customer also, of course, has to contend with price changes introduced by fluctuating exchange rates.

The table shows the state of affairs for nuclear magnetic resonance (NMR), infrared (IR) and ultraviolet (UV) spectroscopy and for gas chromatography (GC). The prices in brackets are the prices today and the others are the prices ten years ago.

\title{
Oil on troubled waters
}

A SYMPOSIUM on hydrocarbons in the marine environment has been postponed by the Ministry of Agriculture because they do not think the meeting is necessary. The organisers, the Torry Research Institute and the Marine Research Station at Aberdeen, planned to discuss the effects of oil pollution at Aberdeen in May. About 100 scientists said they would attend, but they are now being told that the symposium has been postponed. Apparently, somebody who should have been asked wasn't. The Ministry of Agriculture's Administrative Officer, Mr W. R. Small, explained that the symposium is not necessary because there are "six or seven" other symposia going on which deal with the same, or allied, subjects. "This should never have been mooted in the first place without the right people being asked",

\section{More planning problems at Loch Carron}

THE public inquiry into setting up deepsea oil platform construction sites at Drumbuie, Loch Carron on the west coast of Scotland opened again on March 18 after being adjourned for several weeks, but was immediately adjourned again at the request of the National Trust for Scotland, the main objector. The trust was opposed to an entirely unexpected environmental report being placed as evidence.

The trust owns the land on which the platforms will be built if the Drumbuie site is approved for development. They were objecting to a surprise environmental report commissioned by the Scottish Development Department from Sphere Environment Consultants of London. This report considered several other possible sites in the area. None of the objectors had been told that the report was in preparation and their counsel successfully moved for an adjournment until April 1.

The National Trust and the other ob- he thought. "There is simply no unanimity about the urgency of the symposium at this stage. There is a limited corpus of scientists scurrying around these meetings, and at this moment the ministry cannot afford to have its resources spent unnecessarily. You know, it's like a Beau Geste fort, with the same men appearing at different battlements all the time."

A corollary to this spirited assessment of the marine biologist's round is that the men who appear at the battlements on home ground tend to include a fair proportion of junior scientists who are actually engaged in research in the field. The overseas junkets are sometimes made up of more senior men who count foreign travel among their hobbies. The Aberdeen cancellation note points out that the symposium would have clashed with a similar meeting in Maryland-a conjunction which might have caused a crisis of conscience among the senior men, but would not have presented a problem to the junior workers who would have been glad of the chance to talk about pollution problems on their own doorsteps.

Furthermore, Aberdeen is not doing at all badly for profits from services related to the offshore oil industry at the moment and some people would not really be interested to hear about hydrocarbon pollution if oil ran ankle deep in the streets. The Scottish press is keen to pick on stories involving damage to the environment and would almost certainly have been looking for pickings at the Aberdeen symposium. There was a chance that the benefactions of the oil industry would be called into question. This has now been avoided.

jectors had finished giving their evidence against the development when the inquiry was adjourned in February, and this new development will considerably prolong matters. The environmental report and an expected consulting engineer's report, commissioned by the Department of Energy, both come out in favour of Drumbuie as opposed to other sites in the area but give alternatives if the National Trust land does not become available. As the proposed bill to nationalise land needed for oil platform construction is not going ahead under the new Labour government, a special bill in Parliament will be needed to use the trust's land.

Sphere suggested a site on the Isle of Skye near Broadford Bay as their second choice. On the other hand the consulting engineer's report gives a site on Loch Kishorn, near Carron, as the second choice and Broadford Bay as the third.

\section{Australian science news}

Peter Pockley, Sydney

IN a speech to the Science and Industry Forum of the Australian Academy of Science in February, Dr Moss Cass, the Minister for the Environment and Conservation, announced the formation of a new Bureau of Environmental Studies within his department. In doing so, Dr Cass has rejected alternative proposals for establishing a statutory institute, or for strengthening the existing responsibility for some environmental research within the Commonwealth Scientific and Industrial Research Organisation (CSIRO), which in any case comes under the Minister for Science, thus revealing the old problem of duplication where departments overlap.

The Bureau of Environmental Studies will have three main areas of responsibility. First, it will survey, assess and integrate existing studies done by other groups. Second, it will develop programmes to fill identifiable gaps. A third group in the bureau will try its hand at environmental 'futurology', with the aim of anticipating the problems of 20 to 30 years ahead. Here we see the strong strand of anti-industrial growth and humanism in Dr Cass's philosophy, for this group will be charged with developing some kind of human progress index. For this, Dr Cass suggests the term 'gross domestic welfare', which he hopes could be derived from a combination of measures of environmental quality, social indicators and productive capacity in both goods and services. Recruitment for the bureau's staff will start shortly. It looks as though they will need to be in the market for social philosophers as much as ecologists.

- In a further move indicating the diplomatic initiatives between the Australian Labor government and the communist world, the first exchange of visits between Australian and Chinese scientists was announced recently. A party of nine Australians started an 18day visit to Canton, Peking, Shanghai and other centres on March 18. The party of four representatives of the Australian Academy of Science, four from the Australian National University (ANU), and one Asian scholar as interpreter will be led jointly by Professor Sir Rutherford Robertson, President of the Academy, and $\operatorname{Dr} \mathbf{R}$. M. Williams, Vice-Chancellor of ANU. The inclusion of an interpreter chosen by Australia is seen as a significant advantage for the party; he is Professor Liu Ts-un-yan, Head of the Department of Chinese at the ANU.

The scientific interests of the Australians include astronomy, spectroscopy, plant physiology, genetics, mathematical 